\title{
Emergency reversal of warfarin anticoagulation
}

\section{Yulia Lin MD, Jeannie Callum MD}

Previously published at www.cmaj.ca

Emergency reversal of warfarin anticoagulation is required when a patient has major bleeding or needs an urgent procedure

Blood products, such as prothrombin complex concentrate, should be used only when the international normalized ratio (INR) is at least 1.5 and the patient has major bleeding (e.g., intracranial hemorrhage) or needs a procedure within six hours (e.g., repair of a ruptured aortic aneurysm or perforated viscus). For elective reversal, guidelines support withholding warfarin or administering vitamin $\mathrm{K} .{ }^{1}$
Vitamin $\mathrm{K}$ should be given intravenously at the time of emergency reversal of anticoagulation

Because of the temporary effects of blood products, vitamin $\mathrm{K}$ is required for sustained reversal of anticoagulation. The recommended dose is $10 \mathrm{mg}$ in travenously. ${ }^{1}$ The intravenous route acts more quickly than the oral route (6-12 hours v. 18-24 hours). ${ }^{2}$

\section{Prothrombin complex concentrate is the preferred choice for emergency reversal of warfarin anticoagulation}

Prothrombin complex concentrate is a human-derived blood product containing the vitamin $\mathrm{K}$-dependent clotting factors (II, VII, IX, X, protein C and protein S) and heparin. This product is therefore contraindicated in patients with heparin-induced thrombocytopenia. In a prospective multicentre observational study, prothrombin complex concentrate rapidly and consistently corrected the INR. ${ }^{3}$ Comparison with plasma is shown in Table 1.

Table 1: Characteristics of prothrombin complex concentrate and frozen plasma

\begin{tabular}{|c|c|c|}
\hline Characteristic & $\begin{array}{l}\text { Prothrombin complex } \\
\text { concentrate }\end{array}$ & Frozen plasma \\
\hline Viral inactivation & $\begin{array}{l}\text { Solvent/detergent treated } \\
\text { and prion-reduction process }\end{array}$ & $\begin{array}{l}\text { No viral inactivation or prion- } \\
\text { reduction process }\end{array}$ \\
\hline$A B O$ group & $A B O$ typing not required & Must be $A B O$ compatible \\
\hline Preparation time & $\begin{array}{l}5 \text { minutes to reconstitute } \\
\text { lyophilized product }\end{array}$ & $\begin{array}{l}30 \text { minutes to thaw } \\
+10 \text { minutes for } A B O \text { typing }\end{array}$ \\
\hline Volume & $40 \mathrm{~mL}$ for $1000 \mathrm{IU} *$ & Typically 1 L (15 mL/kg) \\
\hline Administration time & 15 minutes per $1000 \mathrm{IU}$ * & 2-4 hours \\
\hline Duration of action & 6 hourst & 6 hourst \\
\hline Caution & $\begin{array}{l}\text { Use with caution in patients } \\
\text { with recent history of arterial } \\
\text { or venous thrombosis }\end{array}$ & $\begin{array}{l}\text { Use with caution in patients } \\
\text { with recent history of arterial } \\
\text { or venous thrombosis }\end{array}$ \\
\hline
\end{tabular}

*Volume and administration time are listed for Octaplex, the only formulation currently available in Canada, and may vary with other prothrombin complex concentrates.

tIf the patient is undergoing a procedure, administer the product as close to the procedure time as possible.

From the Department of Clinical Pathology, Sunnybrook Health Sciences Centre, and the Department of Laboratory Medicine and Pathobiology, University of Toronto, Toronto, Ont.

CMAJ 2010. DOI:10.1503/cmaj100983
The effect of prothrombin complex concentrate and frozen plasma is temporary

The duration of effect is based on the short half-life of factor VII (about six hours). ${ }^{1}$ As a result, the effect of both products decreases after six hours.

The dose of prothrombin complex concentrate depends on the patient's weight and INR

National guidelines suggest 1000 IU of Octaplex, the formulation currently available in Canada, with adjustment of the dose for extremes of weight and INR. ${ }^{4}$ Regimens based on weight and INR are recommended in the product monograph and observational studies. ${ }^{3.5}$ Local hospital guidelines should be developed for recommended doses. The patient's INR needs to be determined within 30 minutes after administration to ensure adequate reversal of anticoagulation.

This article has been peer reviewed.

Competing interests: Yulia Lin is a site investigator for a registry on the off-label use of recombinant factor VIIa that is funded by an unrestricted educational grant from Novo Nordisk; she receives no personal financial payments for participation. No competing interests declared by Jeannie Callum.

The references are in Appendix 1 (available at www.cmaj.ca/cgi/content/full/cmaj.100983/DC1). 